\title{
ZJazd KaTEDR PRAWA RZYMSKIEGO SUCHA BESKIDZKA 8-12 CZERWCA 2005 R.
}

W dniach 8-12 czerwca 2005 r. odbyło się zorganizowane przez Katedrę Prawa Rzymskiego Uniwersytetu Jagiellońskiego Spotkanie Romanistów w Suchej Beskidzkiej. Wzięli w nim udział przedstawiciele wszystkich ośrodków uniwersyteckich przedstawiając 22 referaty o różnorodnej tematyce.

Obrady rozpoczęły się w czwartek, 9 czerwca. Otworzył je prof. Janusz Sondel z Uniwersytetu Jagiellońskiego. Profesor powitał przybyłych, a następnie zwrócił się z prośbą o przedstawienie poszczególnych ośrodków naukowych reprezentowanych przez uczestników.

Po uroczystym rozpoczęciu odbyły się obrady. Przewodniczył w tym dniu prof. Witoldowi Wołodkiewiczowi z Uniwersytetu Warszawskiego. Sesja południowa podzielona została na trzy bloki tematyczne. Pierwszy dotyczył zagadnień prawa karnego i wojskowego i wówczas referaty przedstawili: mgr Piotr Kołodko z Uniwersytetu w Białymstoku - Rzymska terminologia stosowana na określenie narzędzi stosowanych podczas chtosty, mgr Maciej Jońca z Katolickiego Uniwersytetu Lubelskiego - 'Lex Pompeia de parricidiis'. Data uchwalenia ustawy $i$ jej treść, mgr Elżbieta Loska z Uniwersytetu Kardynała Stefana Wyszyńskiego w Warszawie Zbrodnicze zamiary a istnienie obrony koniecznej w prawie rzymskim oraz mgr Tomasz Szeląg z UJ - Kary i odznaczenia w rzymskim prawie wojskowym. Problematykę prawa rodzinnego, której poświęcony został drugi blok tematyczny, przybliżyła dr Elżbieta Ejankowska z Uniwersytetu Rzeszowskiego mówiąca o Potożeniu prawnym filiae familias $i$ jej udziale $w$ obrocie prawno-gospodarczym państwa rzymskiego w okresie późnej republiki i pryncypatu. W ramach trzeciego bloku dotyczącego prawa publicznego referat na temat $\mathrm{Za}$ dań municipium $w$ świetle 'lex Irnitana'. Przyczynek do studiów nad prawem municypalnym $w$ starożytnym Rzymie przedstawił prof. Bronisław Sitek z Uniwersytetu Warmińsko-Mazurskiego oraz referat $\mathrm{z}$ zakresu prawa procesowego, zatytułowany Postępowanie 
w sprawach o 'crimen laesae maiestatis' przedstawiła dr Marzena Dyjakowska z KUL-u.

Następnie prof. Witold Wołodkiewicz otworzył i kierował dyskusją.

Obrady wznowione w ramach sesji popołudniowej, którym nadal przewodniczył prof. Witold Wołodkiewicz, zostały podzielone również na trzy bloki tematyczne. Pierwszy stanowił kontynuację rozpoczętych przed przerwą rozważań na temat prawa publicznego. Przedstawiony został wówczas referat mgr Anny Tarwackiej z UKSW - 'Hostis an latrunculus' - status piratów w świetle 'ius gentium' i rzymskiego prawa prywatnego. Następnie głos zabrał dr Jacek Wiewiorowski z Uniwersytetu Adama Mickiewicza w Poznaniu 'Comes Hispaniarum' jako specjalny wystannik cesarza Konstantyna Wielkiego, a następnie mgr Marek Stus z UJ - Egipt pod panowaniem rzymskim (30 p. n. e.-395 n. e.). Kilka uwag o ustroju prowincji. Drugi blok tematyczny poświęcony ekonomicznym aspektom zobowiązań przybliżyli w swoich referatach mgr Karolina Chytła z UJ Ekonomiczno-prawne przyczyny zawierania kontraktów 'emptio rei speratae' $i$ 'emptio spei' $w$ starożytnym Rzymie oraz mgr Paulina Swięcicka-Wystrychowska z UJ - Ekonomiczne aspekty i ekonomiczna analiza odpowiedzialności akwiliańskiej. Sesję zakończył referat mgr Moniki Koncur z UAM dotyczący zagadnień prawa rzeczowego, zatytułowany Skarga negatoryjna we wczesnych tekstach jurysprudencji rzymskiej. Jako ostatni swój referat - Wplyw cesarzy rzymskich na wybór papiezy wygłosił ks. prof. Florian Lempa z UwB. Po przedstawieniu tych referatów odbyła się dyskusja.

W piątek w sesji porannej moderatorem obrad był prof. Jan Zabłocki z UKSW. Dotyczyły one dwóch bloków tematycznych, z których pierwszy poświęcony był wpływom prawa rzymskiego na prawo współczesne, drugi zaś filozofii i teorii. W ramach pierwszego bloku tematycznego głos zabrali: mgr Aldona Jurewicz z UW-M Domniemanie ojcostwa, mgr Marek Sobczyk z Uniwersytetu Mikołaja Kopernika w Toruniu - Wptyw prawa rzymskiego na ksztattowanie się wspótczesnych teorii sity wyższej oraz prof. Wojciech Dajczak z UAM - Zblizenie romanistyki i komparatystyki prawniczej - szansa na twórczy rozwój, czy źródto stabości badań prawno-porównaw- 
czych? Drugi blok tematyczny poświęcony zagadnieniom z zakresu filozofii i teorii rozpoczął referat ks. dr hab. Franciszek Longchamps de Bérier z UW zatytułowany Summum ius summa iniuria. O ideologicznych zatożeniach $w$ interpretacji starożytnych tekstów źródtowych. Następnie swój referat przedstawił dr Ewaryst Kowalczyk z UAM - Chrześcijańska dobroczynność w prawie rzymskim. Sesja zakończyła się żywą dyskusją.

W sesji popołudniowej obrady prowadziła prof. Maria Zabłocka z UW. Referaty zaś referaty dotyczyły problematyki wpływów prawa rzymskiego w czasach nowożytnych. Jako pierwszy swój referat wygłosił dr Ireneusz Jakubowski z Uniwersytetu Łódzkiego - Prawo rzymskie w rozprawie Tadeusza Czackiego 'O Żydach i Karaitach'. Kolejnymi prelegentami byli: dr Łukasz Marzec z UJ - Artur Duck, De usu auctoritate ... - podrzędna rozprawa czy dzieto światowej romanistyki oraz dr Krzysztof Amielańczyk z UMCS - Gtos Hadriana $w$ sprawie 'Senatus Consultum Silanianum'. Po wysłuchaniu powyższych referatów, Przewodnicząca podjęła wciąż żywy temat Przysztości polskiej romanistyki. W swoim wystąpieniu poruszyła dwie zasadnicze kwestie. Pierwsza odnosiła się do badań naukowych, których ciągły rozwój, a także napływającą młodą, ambitną kadrę, uznała za dające optymistyczny obraz romanistyki polskiej w przyszłości. Z kolei druga kwestia, dotycząca przyszłości prawa rzymskiego jako przedmiotu wykładanego na uczelniach krajowych, została, przez prof. Marię Zabłocką, uznana za nieco bardziej dyskusyjną. Prelegentka wyraziwszy własne sugestie co do sposobu wykładania tego przedmiotu, zachęciła zebranych do udziału w dyskusji, która stała się bardzo ożywiona. Obrady zakończył główny organizator Spotkania, prof. Janusz Sondel, który gorąco podziękował wszystkim za przybycie oraz za przygotowanie wielu interesujących referatów.

W sobotę w godzinach porannych odbyła się wycieczka w pierwszej kolejności do Kalwarii Zebrzydowskiej, gdzie mieści się Sanktuarium Pasyjno-Maryjne oraz Klasztor OO. Bernardynów, który w dniu 1 grudnia 1999 r. został wpisany na Listę Światowego Dziedzictwa Kultury i Natury UNESCO, a nastepnie do Wadowic, gdzie 
uczestnicy mogli podziwiać Bazylikę Ofiarowania Najświętszej Maryi Panny, a także posmakować słynnych kremówek papieskich. Niestety, z uwagi na dużą liczbę turystów, nie udało się zwiedzić domu rodzinnego Papieża Jana Pawła II.

Wycieczka do Wadowic była ostatnim punktem programu Spotkania Romanistów w Suchej Beskidzkiej.

Renata Kamińska*

\footnotetext{
* Uniwersytet Kardynała Stefana Wyszyńskiego.
} 